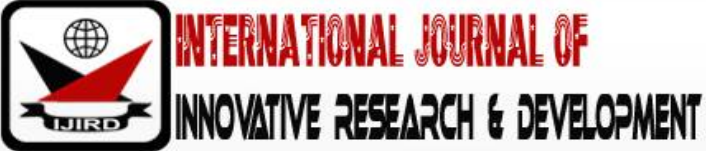

ISSN 2278 - 0211 (Online)

\section{Heavy Metal Contamination of Groundwater: An Effect of Dump Site Leachate Percolation, Case Study; Selected Dump Sites of Osubi, Western Niger-Delta}

\begin{tabular}{c} 
Okumoko Dokumo Pearce \\
Lecturer, Department of Earth Sciences, \\
Federal University of Petroleum Resources, Effurun, Nigeria \\
Izeze Elijah Ovie \\
Lecturer, Department of Earth Sciences, \\
Federal University of Petroleum Resources, Effurun, Nigeria \\
\hline
\end{tabular}

\begin{abstract}
:
The status of the quality of groundwater in Osubi area of Delta State is reviewed in this paper. For this study 10 stations (wells) around abattoir dumpsite in Osubi, Delta state were chosen to collect and assess copper, lead, manganese, cadmium and iron contamination in groundwater using methods as pollution load index (PLI) and geo-accumulation index (I-geo). Cadmium and lead had the lowest concentration as they were not detected, whereas iron had the highest concentration ranging from not detected to $45.45 \mathrm{mg} / \mathrm{kg}$ with 13.48492 as average, manganese ranging from 0.03 to 0.77 with $0.192 \mathrm{~s}$ average and copper with 0.2 in only well 6. Methods as enrichment factor, Pearson's correlation coefficient, one-way Anova, and cluster analysis was used to evaluate the relationships between the growing heavy metal concentration. Geo-accumulation index indicated that well 4, 5 and 6 were the most polluted with respect to manganese with values ranging from - 1.90689 at the least to 2.35989 at the most, iron with values ranging from -7.67243 at the least to 2.155711 at the most and copper, with value 5.058894 at the most. Enrichment factor results indicated that cupper in well 6 was the most enriched relative to iron with value as high as110.7492. The one-way Anova and cluster dedrogram indicated that most of the heavy were closely related in concentration and growth as only two clusters were represented. All methods used indicated that the study unpolluted to moderately polluted and polluted was anthropogenic and not geogenic.
\end{abstract}

Keywords: Osubi, enrichment factor, cluster analysis, correlation, Anova

\section{Introduction}

Delta state with a population of about 4.1 million people is a highly industrialized state in Nigeria. About 650 700 thousand metric tons of wastes were deposited into various landfill sites in delta annually for the last 5 years. Many existing and abandoned landfills pose serious detrimental health impacts to the environment. Unfortunately, the quality of groundwater has been impaired by indiscriminate dumping of solid waste materials in landfill within municipality (Afzal .M., Elahe, A.P., 2008), with attended risk to the health of the people and damage to the environment .Industrial development and uncontrolled increase of rural-urban migration that leads to the growth of the urban population have resulted in an increase in the population of different types of waste ranging from industrial to municipal, which have adverse effects on human populace.This study evaluates the trace and elements (copper, lead, Cadmium, Manganese, iron) composition of water of ground water around two dumpsites (both active) in selected areas in Delta and the leaching potential of these elements from waste soils with a view to assessing the potential contamination of the groundwater resources near the dump sites. Recent day waste disposal systems and management are way more advanced than it was in the past decades as modern techniques and facilities are now being employed in the collection, dumping, recollection and recycling of waste (Chu L.M., Cheung K.C., Wong M.H., 1994). But still society still has to deal with the problem of excessive waste intake and less rate of recycling more and more dumpsites are created daily mostly in urban areas where the urbanrural migration is not controlled. Industrial, agricultural and municipal waste keep on accumulating leading more and more leachate infiltration in groundwater.

Leachate is defined as any contaminated liquid that is generated from water percolating through a solid waste disposal site, accumulating contaminants, and moving into subsurface areas ultimately targeting groundwater. A second source of leachate arises from high moisture content of certain disposed wastes. As these wastes are compacted or chemically react, bound water is released as "leachate". In the absence of confining barrier beneath or surrounding the dumpsite, this leachate can migrate and contaminate both groundwater and surface waters. The volume leachate generated depends on different variables such as storm-water runoff, rain-water runoff, volume of groundwater 
entering(encroaching) the waste containing zone, moisture content and absorbent capacity of waste materials, topography, rate of waste deposition, amount of rainfall, rate of recollection for recycling, temperature, etc. factors that affect the rate of leachate infiltration in groundwater are proximity of water table to surface, porosity and permeability of underlying rock. Furthermore, the impact of leachate in an environ is highly dependent on the age of the dumpsite, consequently older dumpsite is more stabilized and may generate lower concentrations of organics as they are degradable, leaving just very toxic cations of heavy metals, anions. Leachate on their own contains a host of toxic and carcinogenic chemicals, which may cause harm to both human and the environment (Lee G.F., Jones-Lee .R.A, 1996). Contaminated groundwater by leachate can adversely affect industrial and agricultural activities that depend on well water. For certain industries, contaminated water may affect product quality, decrease equipment life time, or require pre-treatment of the water supply, all of which cause additional financial expenditures. The use of contaminated water for irrigation activities can decrease soil productivity, contaminate crops, and possibly move toxic pollutant up the food chain as animal and human crops grown in an area irrigated with contaminated water.

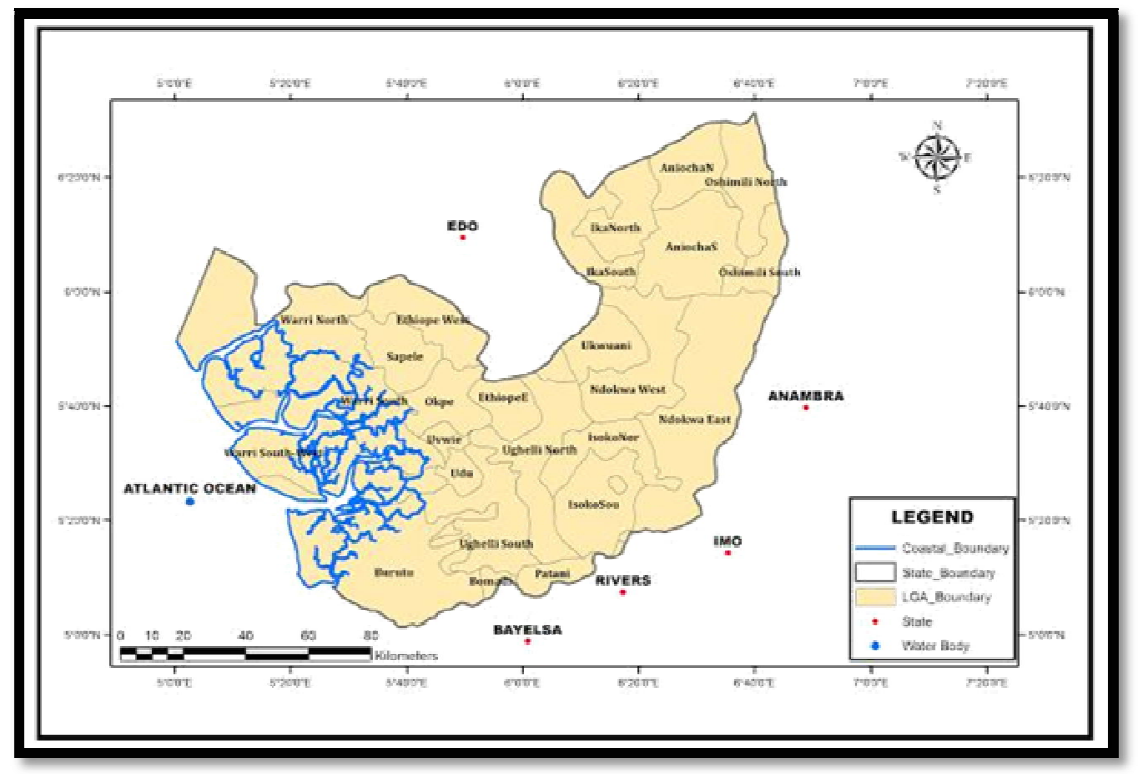

Figure 1: Map of Delta State Nigeria, Produced Using Arc-GIS Software of ESRI. Copyright of Gamers 2017

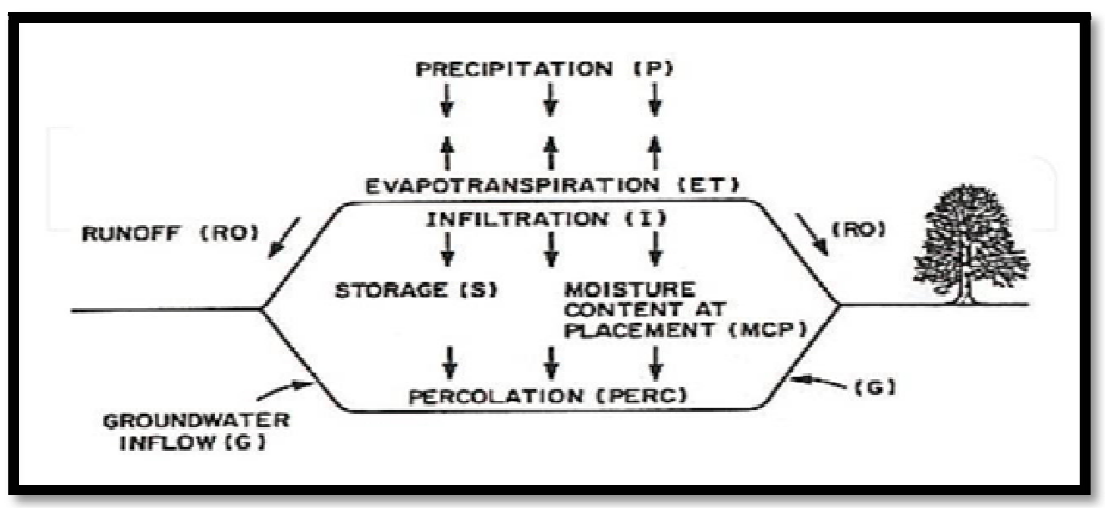

Figure 2: Generalized Pattern of Leachate Generation Farquhar Gj. (1989) Leachate: Production and Characterization. Canadian Journal of Civil Engineering

\section{Study Area}

\subsection{Osubi}

Osubi is a town close to Warri in Okpe Local Government Area of Delta state, southern Nigeria. The population is approximately over 8000 people Osubi lies between coordinates $5^{\circ} 35^{\prime} 50^{\prime \prime} \mathrm{N}$ and $5^{\circ} 49^{\prime} 10^{\prime \prime}$ E. Warri Airport (also known as Osubi Airstrip) is located in Osubi. There is a rapid infrastructural development (Oboh I.P., Egun N.K., Olowo U.C., Nwaokolo J.I., 2018) mostly around the airport region due to the closeness and prominence to the Niger Delta oilproducing area of Nigeria. 


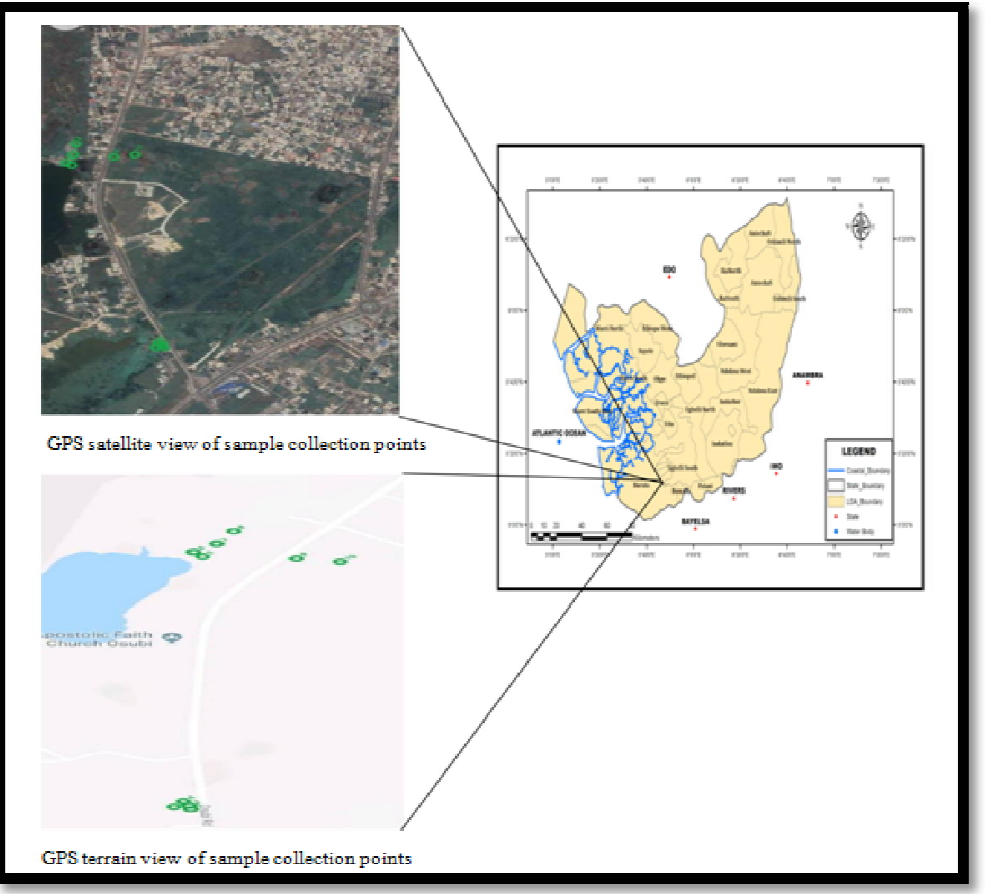

Figure 3: GPS View of Osubi Showing Sampling Points from Both Wings of Abbatoir Dumpsite

\subsection{GPS Location of Sampling Points}

\begin{tabular}{|c|c|c|}
\hline Point & Longitude Degree & Latitude Degree \\
\hline Osubi 1 & $5^{0} 34^{\prime} 34.8528^{\prime \prime}$ & $5^{0} 48^{\prime} 4.6872^{\prime \prime}$ \\
\hline Osubi 2 & $5^{0} 34^{\prime} 36.9588^{\prime \prime}$ & $5^{0} 48^{\prime} 5.022^{\prime \prime}$ \\
\hline Osubi 3 & $5^{0} 34^{\prime} 36.0012^{\prime \prime}$ & $5^{0} 48^{\prime} 3.69^{\prime \prime}$ \\
\hline Osubi 4 & $5^{0} 34^{\prime} 36.5268^{\prime \prime}$ & $5^{0} 48^{\prime} 7.3692^{\prime \prime}$ \\
\hline Osubi 5 & $5^{0} 35^{\prime} 14.6112^{\prime \prime}$ & $5^{0} 48^{\prime} 47.25^{\prime \prime}$ \\
\hline Osubi 6 & $5^{0} 35^{\prime} 10.2768^{\prime \prime}$ & $5^{0} 48^{\prime} 37.0188^{\prime \prime}$ \\
\hline Osubi 7 & $5^{0} 35^{\prime} 8.826^{\prime \prime}$ & $5^{0} 48^{\prime} 37.3428^{\prime \prime}$ \\
\hline Osubi 8 & $5^{0} 35^{\prime} 9.3841^{\prime \prime}$ & $5^{0} 48^{\prime} 39.4992^{\prime \prime}$ \\
\hline Osubi 9 & $5^{0} 35^{\prime} 9.5928^{\prime \prime}$ & $5^{0} 48^{\prime} 46.7388^{\prime \prime}$ \\
\hline Osubi 10 & $5^{0} 35^{\prime} 5.19^{\prime \prime}$ & $5^{0} 48^{\prime} 51.7932^{\prime \prime}$ \\
\hline
\end{tabular}

Table 1: GPS Location of Sampling Points

\begin{tabular}{|c|c|c|}
\hline Class & I geo Value & Quality \\
\hline 0 & I geo $\leq 0$ & Uncontaminated \\
\hline 1 & $0<$ Igeo $<1$ & Uncontaminated to moderately contaminated \\
\hline 2 & $1<$ Igeo $<2$ & Moderately contaminated \\
\hline 3 & $2<$ Igeo $<3$ & Moderately to heavily contaminated \\
\hline 4 & $3<$ Igeo $<4$ & Heavily contaminated \\
\hline 5 & $4<$ Igeo $<5$ & Heavily to extremely contaminated \\
\hline 6 & $5<$ Igeo & Extremely contaminated \\
\hline
\end{tabular}

Table 2: Geo - Accumulation Index Proposed by (Muller.G., 1969)

\subsubsection{Enrichment Factor}

Enrichment factor (EF) is popularly used to determine whether the sources of the metals are geogenic and/or anthropogenic as well as to assess the degree of metal contamination, EF values from 1 to 10 indicate geogenic sources (natural source), while those

\begin{tabular}{|c|l|}
\hline$<2$ & Minimal enrichment \\
\hline $2-5$ & Moderate enrichment \\
\hline $5-20$ & Significant enrichment \\
\hline $20-40$ & Very highly enriched \\
\hline$>40$ & Extremely highly enriched \\
\hline
\end{tabular}

Table 3: Enrichment Factor by (Sutherland R.A., 2000) 


\section{Results and Discussions}

\begin{tabular}{|c|c|c|c|c|c|}
\hline & $\mathbf{C u}$ & $\mathbf{P b}$ & Mn & Cd & $\mathbf{F e}$ \\
\hline Osubi 1 & 0 & 0 & 0.04 & 0 & 0.14 \\
\hline Osubi 2 & 0 & 0 & 0.03 & 0 & 0 \\
\hline Osubi 3 & 0 & 0 & 0.03 & 0 & 0.28 \\
\hline Osubi 4 & 0 & 0 & 0.65 & 0 & 10.33 \\
\hline Osubi 5 & 0 & 0 & 0.77 & 0 & 45.45 \\
\hline Osubi 6 & 0.2 & 0 & 0.2 & 0 & 3.07 \\
\hline Osubi 7 & 0 & 0 & 0.04 & 0 & 0.69 \\
\hline Osubi 8 & 0 & 0 & 0.03 & 0 & 0.05 \\
\hline Osubi 9 & 0 & 0 & 0.05 & 0 & 0.33 \\
\hline Osubi 10 & 0 & 0 & 0.08 & 0 & 0 \\
\hline WHO 2011 & 2.0 & 0.01 & 0.10 & 0.003 & 0.1 \\
\hline NSDWQ 2007 & 1.0 & 0.01 & 0.20 & 0.003 & 0.3 \\
\hline Max value & 0.2 & 0 & 0.77 & 0 & 45.45 \\
\hline Minimum value & 0 & 0 & 0.03 & 0 & 0 \\
\hline mean & 0.02 & 0 & 0.192 & 0 & 6.034 \\
\hline Standard deviation & 0.06 & 0 & 0.26487 & 0 & 13.48492 \\
\hline
\end{tabular}

Table 4: Atomic Absorption Spectrophotometer Analysis Results for Heavy Metal Concentration in Water Samples

\begin{tabular}{|c|c|c|l|c|c|}
\hline Locations & Cu & Pb & Mn & Cd & Fe \\
\hline Osubi 1 & ND & ND & -1.90689 & ND & -6.187 \\
\hline Osubi 2 & ND & ND & -2.32193 & ND & ND \\
\hline Osubi 3 & ND & ND & -2.32193 & ND & 0.018271 \\
\hline Osubi 4 & ND & ND & 2.115477 & ND & 2.155711 \\
\hline Osubi 5 & ND & ND & 2.359896 & ND & -1.73226 \\
\hline Osubi 6 & 5.058894 & ND & 0.415037 & ND & -3.88583 \\
\hline Osubi 7 & ND & ND & -1.90689 & ND & -7.67243 \\
\hline Osubi 8 & ND & ND & -2.32193 & ND & -4.94996 \\
\hline Osubi 9 & ND & ND & -1.58496 & ND & ND \\
\hline Osubi 10 & ND & ND & -0.90689 & & \\
\hline
\end{tabular}

Table 5: Geo-Accumulation Index

\begin{tabular}{|c|c|c|c|c|c|c|}
\hline Location & Cu & Pb & Mn & Cd & Fe & PLI \\
\hline OSUBI 1 & ND & ND & 0.266667 & ND & 0.013725 & 0.060499 \\
\hline OSUBI 2 & ND & ND & 0.2 & ND & ND & 0.2 \\
\hline OSUBI 3 & ND & ND & 0.2 & ND & 0.027451 & 0.074096 \\
\hline OSUBI 4 & ND & ND & 4.333333 & ND & 1.012745 & 0.344897 \\
\hline OSUBI 5 & ND & ND & 5.133333 & ND & 4.455882 & 4.782628 \\
\hline OSUBI 6 & 33.33333 & ND & 1.333333 & ND & 0.30098 & 2.373841 \\
\hline OSUBI 7 & ND & ND & 0.266667 & ND & 0.067647 & 0.13431 \\
\hline OSUBI 8 & ND & ND & 0.2 & ND & 0.004902 & 0.031311 \\
\hline OSUBI 9 & ND & ND & 0.333333 & ND & 0.032353 & 0.103848 \\
\hline OSUBI 10 & ND & ND & 0.533333 & ND & ND & 0.533333 \\
\hline
\end{tabular}

Table 6: Contamination Factor Pollution Load Index

\begin{tabular}{|c|c|c|c|c|}
\hline Location & Cu & Pb & Mn & Cd \\
\hline OSUBI 1 & ND & ND & 19.42857 & ND \\
\hline OSUBI 2 & ND & ND & ND & ND \\
\hline OSUBI 3 & ND & ND & 7.285714 & ND \\
\hline OSUBI 4 & ND & ND & 1.2788 & ND \\
\hline OSUBI 5 & ND & ND & 4.429967 & ND \\
\hline OSUBI 6 & N10.7492 & ND & 3.942029 & ND \\
\hline OSUBI 7 & ND & ND & ND \\
\hline OSUBI 8 & ND & ND & ND \\
\hline OSUBI 9 & ND & ND & ND & ND \\
\hline OSUBI 10 & ND & ND \\
\hline
\end{tabular}

Table 7: Results Enrichment Factor Relative to Iron 


\section{Discussions and Interpretation}

\subsection{Cupper (CU)}

Copper concentration in the study areas ranges from less than $0.01-0.2 \mathrm{mg} / \mathrm{kg}$ with a mean value of $0.02 \mathrm{mg} / \mathrm{kg}$. The (World health organization , 2008) for this parameter is $2.0 \mathrm{mg} / \mathrm{kg}$ and (NSDWQ, 2007) value of $1.0 \mathrm{mg} / \mathrm{kg}$ therefore, the concentration of cupper is lower than the permissible limit of the stipulated standards but also has significant health impact because it can cause anemia, liver and kidney damage, and stomach and intestinal irritation to human and livestock .The copper present in the water sample at the second wing of the dump (OSUBI 6) shows maximum concentration $(0.2 \mathrm{mg} / \mathrm{kg})$. The main sources of pollution are metallic waste disposal at the dump.

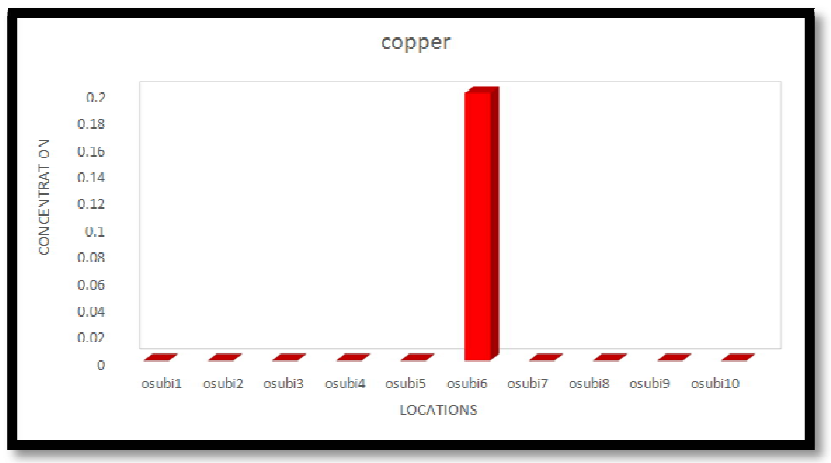

Figure 4: Histogram Showing Concentration of Copper at All Locations

\section{2. $\operatorname{Iron}(\mathrm{Fe})$}

Iron concentration in the study areas ranges from less than $0.01-45.45 \mathrm{mg} / \mathrm{kg}$ with a mean value of $6.034 \mathrm{mg} / \mathrm{kg}$. The (World health organization , 2008) for this parameter is $0.1 \mathrm{mg} / \mathrm{kg}$ and (NSDWQ, 2007) value of $0.3 \mathrm{mg} / \mathrm{kg}$ therefore, the concentration of iron is higher than the permissible limit of the stipulated standards and presents significant health problems as iron concentration at (OSUBI 4) reached up to $10.33 \mathrm{mg} / \mathrm{kg}$ and $45.45 \mathrm{mg} / \mathrm{kg}$ at (OSUBI 5). The main sources of pollution are metallic waste disposal at the dump.

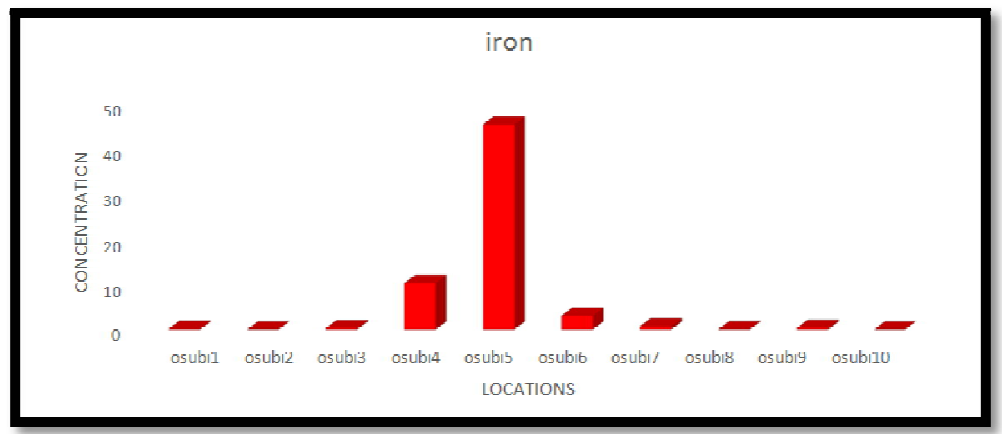

Figure 5: Histogram Showing Concentration of Iron at All Locations

\subsection{Manganese (Mn)}

Manganese concentration in the study areas ranges from less than $0.013-0.77 \mathrm{mg} / \mathrm{kg}$ with a mean value of 0.192 $\mathrm{mg} / \mathrm{kg}$. The (World health organization, 2008) for this parameter range from 0.1-0.2 mg/kg and (NSDWQ, 2007) value of $0.2 \mathrm{mg} / \mathrm{kg}$ therefore, the concentration of manganese is higher than the permissible limit of the stipulated standards at some locations and less at some locations. Significant health problems associated with high manganese concentration could surface at (OSUBI 4) which reached up to $0.65 \mathrm{mg} / \mathrm{kg}$ and $0.77 \mathrm{mg} / \mathrm{kg}$ at (OSUBI 5). The main sources of pollution are metallic waste disposal at the dump.

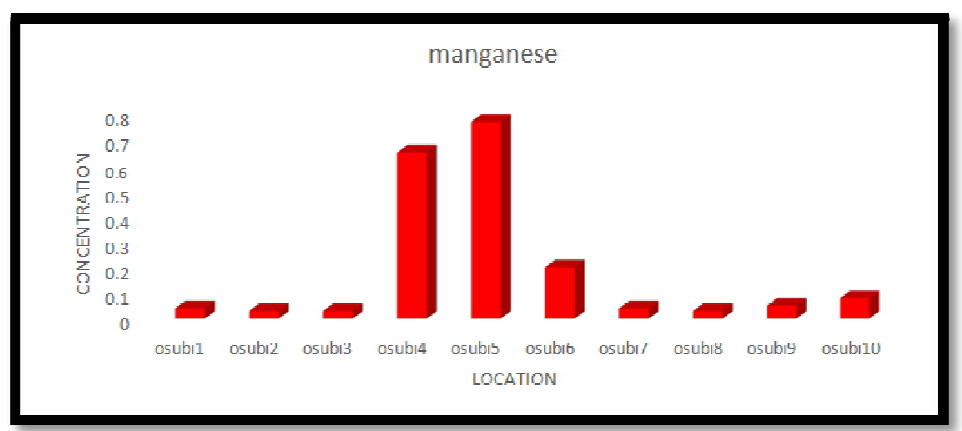

Figure 6: Histogram Showing Concentration of Manganese at All Locations 


\section{Geo-Accumulation Index Interpretation}

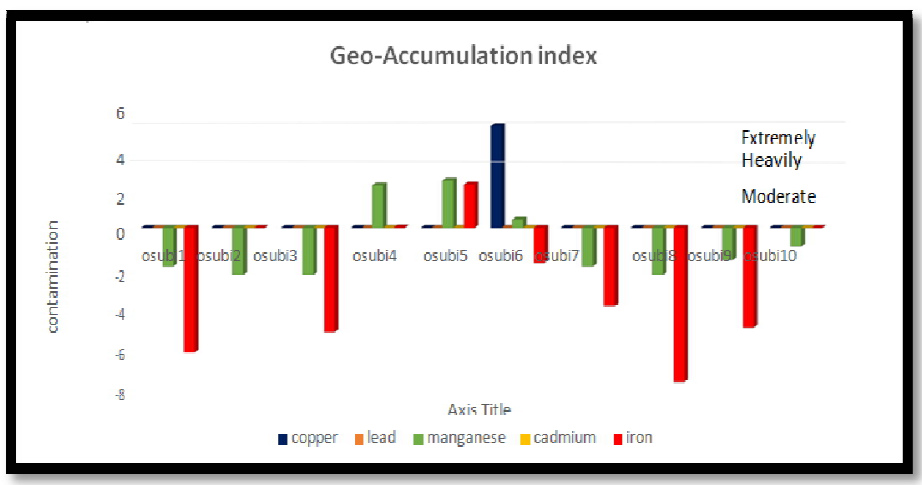

Figure 7: Histogram Showing the Geo-Accumulation Index of Heavy Metals at All Locations

\subsection{Pollution Load Index and Contamination Index Interpretation}

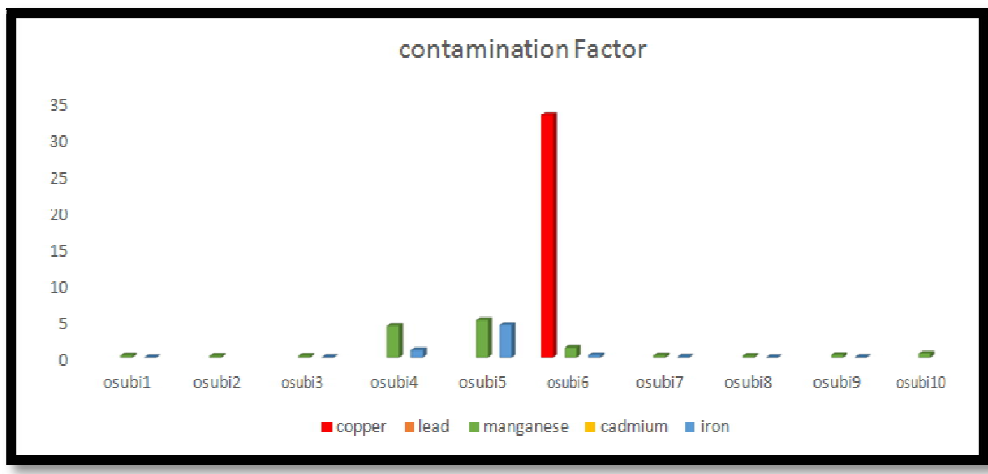

Figure 8: Histogram Showing the Contamination Factor of Heavy Metals at All Locations

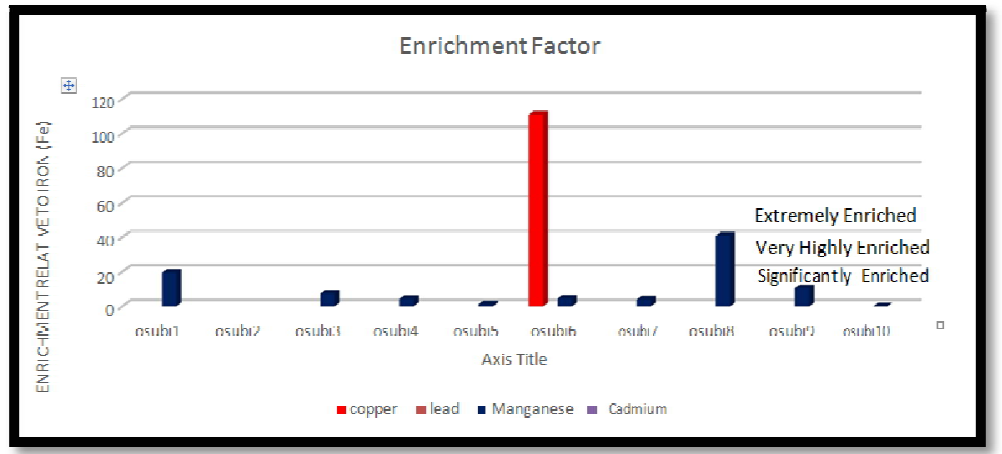

Figure 9: Histogram Showing the Enrichment of Heavy Metals Relative to Concentration of Iron at All Locations

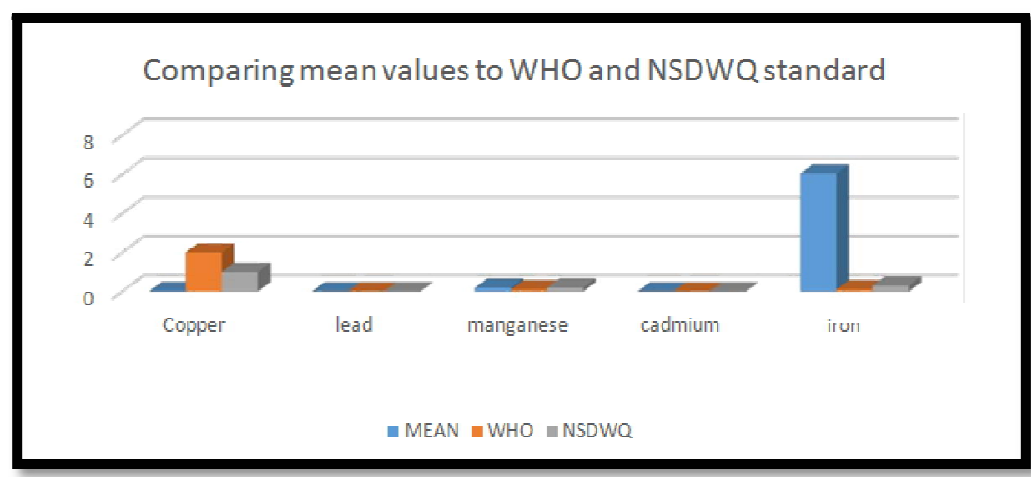

Figure 10: Histogram Comparing the Mean Concentration of Heavy Metals to W.H.O and Nsdwq Standards 


\section{Statistical Analysis}

\subsection{Pearson's Correlation Coefficient}

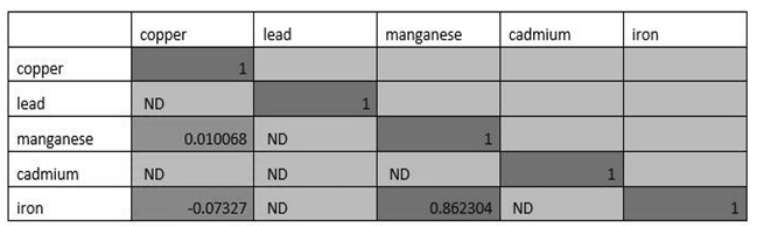

$\Xi$ Not Correlated $\square$ Not Detected $\equiv$ Positivelv Correlated

Table 8: Result of Pearson's Correlation Coefficient

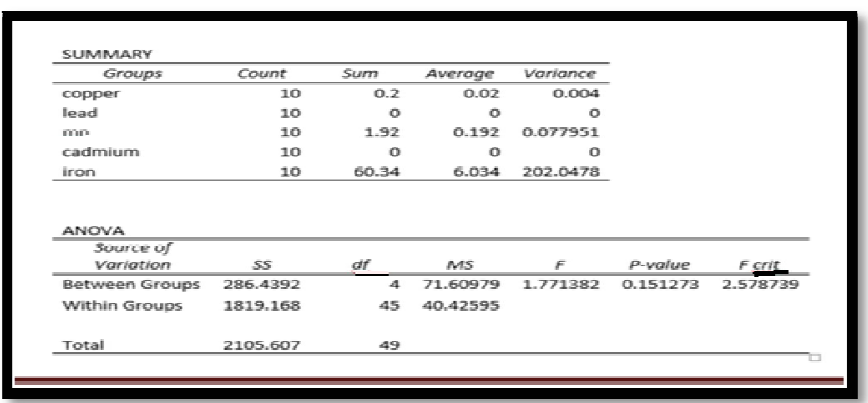

Table 9: Summary and Result S of One-Way Anova

\begin{tabular}{|c|c|c|c|c|c|}
\hline \multirow[t]{2}{*}{ Case } & \multicolumn{4}{|c|}{ Squared Euclidean Distance } & \multirow[b]{2}{*}{ 5:iron } \\
\hline & 1:copper & 2:lead & 3:manganese & 4:cadmium & \\
\hline 1:copper & .000 & .040 & 1.030 & .040 & 2181.334 \\
\hline 2:lead & .040 & .000 & 1.070 & .000 & 2182.522 \\
\hline 3:manganese & 1.030 & 1.070 & .000 & 1.070 & 2098.823 \\
\hline 4:cadmium & .040 & .000 & 1.070 & .000 & 2182.522 \\
\hline 5:iron & 2181.334 & 2182.522 & 2098.823 & 2182.522 & .000 \\
\hline
\end{tabular}

Table 10: Proximity Matrix of Metals with One Another

This cluster analysis was done using the spss software, the results is presented as the proximity matrix table and cluster dendrogram in this report, they are both to even more show relationships between the metal concentrations. For the proximity matrix table, metals which were very closely related in concentration had smaller values, with the smallest being 0.040 in the lead-copper, cadmium-copper, copper-lead, and copper-cadmium matrixes. And the highest being 2182.522 in the iron-copper, copper-iron, iron-lead, lead-iron, and the iron-cadmium, cadmium-iron matrixes. Manganeseiron, iron-manganese had a value of 2098.823, the manganese-lead, lead-manganese and the manganese-cadmium, cadmium-manganese had same value of 1.070. while the copper-manganese, manganese-copper had a value of 1.030 . The cluster dendrogram in this research is an agglomerative (bottom to top) hierarchal clustering where metals are grouped into closely related metals in concentration. Basically two main clusters as the concentration levels of iron is appreciably distinct from the concentration of the other metals which group to form a cluster, although the dendrogram also shows the proximity of the metal concentrations to one another. The concentration of manganese is closest to that of iron, and copper after that with lead and cadmium farthest from iron which forms its own cluster.

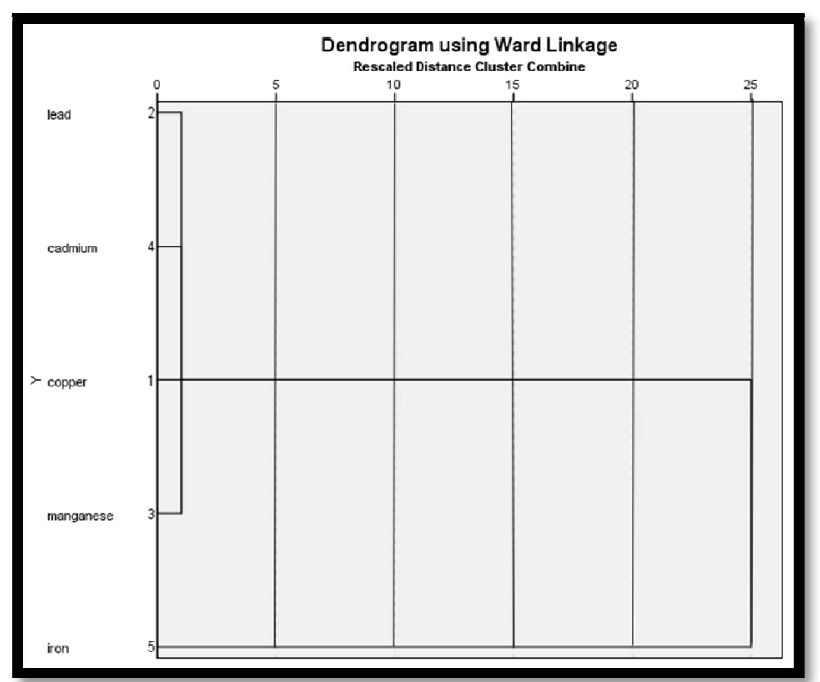

Figure 10: Dendrogram Showing Heavy Metal Clusters 


\section{Conclusion}

In this report considered which factors have an effect on amount values of the elements contained in groundwater along Osubi road in Warri, Nigeria. Results of analysis done on this samples show that the concentration of most the metals examined were below W.H.O and NSDWQ permissible limits except for iron which has a high peak of $45.45 \mathrm{mg} / \mathrm{kg}$. The Pearson's correlation coefficient showed a positive correlation between iron and manganese which indicates increasing concentration at the same pace as the dumpsite is still very active. Results of the enrichment factor revealed although minute, copper was on the fastest growing metal as was absent in the previous years.

\section{Recommendation}

Based on the conclusions made from this research, the following recommendations have been made:

- Adequate disposal facilities should be made available by government authorities and agencies to residential /industrial areas to aid proper refuse collection and effective disposal.

- Public enlightenment of the populations on the adverse effects of heavy metal high concentration to humans and plants.

- Though heavy metal loading of the study area is still within permissible limits. Monitoring and further investigations should be conducted periodically to assess the level of heavy metals in the marine environment of the Western Region in order to assess health risk of the communities.

\section{References}

i. Adedeji, A.A., Ajibade, L.T. (2005). Quality of water in Ede area, southwestern Nigeria. Journalof Human Ecology, Vol. 17, 222-225.

ii. Afolayan, O.S., Ogundele, F.O., and Odewumi, S.G. (2012). Hydrological Implication of Solid Waste Disposal on Groundwater Quality in Urbanized Area of Lagos State, Nigeria. lagos.

iii. Afzal.M., Elahe, A.P. (2008). Groundwater Quality and Sources of Pollution in Baghan Watershed, Iran. World Academy of Science, Engineering and Technology, 101-109.

iv. Akinbile C.O. (2012). Environmental Impact of Landfill on Groundwater Quality and Agricultural Soils in Nigeria. 18.

v. Akinbile O.C., Mohammed S.Y. (2011). Environmental Impact of Leachate Pollution on Groundwater Supplies in Akure, Nigeria. Akure.

vi. Al-Salem S.M.(2009). Life Cycle Assessment of Municipal Solid Waste in Kuwait. .

vii. European Journal of Scientific Research, 34(3), 395-405.

viii. Andreottola G., Cannas P. (1992). Chemical and biological characteristics of landfill leachate.

ix. Elsevier Applied Science. 9., 65-88.

x. Asibor G., Edjere O. (2016). Leachate Characterization and Leachate Pollution Index from Landfill Dumpsites in Warri Metropolis, Nigeria.

xi. Asseez L.0. (1989). Review of the stratigraphy, sedimentation and structure of the Niger Delta.311 -324.

xii. Brassington N. (1988). Field Hydrogeology. Geological Society of London.

xiii. Chiang L., Chang J., Wen T. (1995). Indirect oxidation effect in electrochemical oxidation treatment of landfill leachate. Water Research, 29, 78-671.

xiv. Christensen T.H.K., Albrechtsen P.H.J. (1994). Attenuation of landfill leachate pollutants in aquifers. Critical Reviews in Environmental Science and Technology 24, 119-202.

xv. Chu L.M., Cheung K.C., Wong M.H., (1994). Variations in the chemical properties of landfill leachate. J. Environ. Manage, 105-117.

xvi. Clark.J. (2006). Rivers and their catchments: impact of landfill on water quality. 2.

xvii. Dami A., Ayuba, H.K., Amukali O. (2013). Ground water pollution in Okpai and Beneku, Ndokwa-East Local Government Area, Delta State, Nigeria. Journal of Environmental Research and Management Vol. 4(1)., 163-170.

xviii. Daud Z., Aziz A., Adlan M.N., Hung Y.T. (2009). Application of combined filtration and coagulation for semi-aerobic leachate treatment. International Journal of Environment and Waste Management, 4, 457-469.

xix. Deng Y., Englehardt J. (2006). Treatment of landfill leachate by the Fenton process. Waterre search, 40(20), 943683.

xx. Etu-Efeotor J.O., Akpokodje E.G. (1990). Aquifer systems of the Niger Delta. Journal of Mining Geology. 26 (2), 279285.

xxi. FEPA. (1991). National Interim Guidelines and Standards for Industrial Effluents and Water Quality Tests. Federal Environmental Protection Agency of Nigeria.

xxii. Foul A.A., Aziz H.A., Isa M.H., Hung Y.T. (2009). Primary treatment of anaerobic landfill leachate using activated carbon and limestone Batch and column studies. International Journal of Environment and Waste Management, 4, 282-298

xxiii. Frost R. Griffin R. (1977). Effect of pH on adsorption of arsenic and selenium from landfill leachate by clay minerals. Soil Science Society of America Journal, 41(1), 53-57.

xxiv. Gautam R., Sharma S., Mahiya S., Chattopadhyaya M. (2014). Heavy Metals in Water Presence, Removal and Safety.

xxv. Harikumar P.S., Nasir U.P., Mujeebu R.M.P. (2009). Distribution of heavy metals in the core sediments of a tropical wetland system. International Journal. Environmental Science Technology, Vol. 6, No. 2, 225-232.

xxvi. Ikem A., Osibanjo O., Sridhar M.K.C., Sobande A. (2002). Evaluation of groundwater quality characteristics near two waste sites in Ibadan and Lagos, Nigeria. Water, Air, and Soil Pollution. 307-333. 
xxvii. Inanc B., alh B.C., Saatc A.i. (2000). Characterization and anaerobic treatment of the sanitary landfill leachate in Istanbul. Water Science Technology41., 223-230.

xxviii. International Labour Organization. (1999). International Occupational Safety and Health Information Centre.Geneva.

xxix. Karaca A., Cetin, S.C., Turgay O.C., Kizilkaya R. (2010). Effects of Heavy Metals on Soil Enzyme Activities. Soil Biology, Heidelberg 19, 237-265.

xxx. Lee G.F., Jones-Lee. R.A, (1996). Evaluation of the Potential for a Proposed or Existing Landfill to Pollute Ground Waters. 1-18.

xxxi. Li Q, Logan. B.E. (1999). Enhancing Bacterial Transport for Bio-augmentation of Aquifers Using Low Ionic Strength Solutions and Surfactants.

xxxii. Lide D. (1992). CRC Handbook of Chemistry and Physics. 73rd Edition. Boca Raton, CRC Press.

xxxiii. Longe E.O., Balogun M.R. (2010). Groundwater quality assessment near a municipal landfill, Lagos, Nigeria. Research Journal of Applied Sciences, Engineering and Technology, 2, 39-44.

xxxiv. MacDonald A., Davis J., Calow C. Chilton J. (2005). Developing groundwater, a guide to rural water supply. ITDGS Publishing. U.K.

xxxv. Malina J.F., Pohland F.G. (1996). Design of anaerobic processes for the treatment of industrial and municipal wastes. Water Quality Management. 7., 169-175.

xxxvi. Merki J.P. (1970). Structural Geology of the Cenozoic Niger Delta African Geology. University of Ibadan Press.

xxxvii. Mohajeri S., Aziz M.H., Zahed M.A., Adlan M.N. (2010). Statistical optimization of process parameters for landfill leachate treatment using electro-Fenton technique. 749-758.

xxxviii. Mor. S, Ravindra. K, Dahiya R.P, Chandra. A. (2006). Leachate Characterization and Assessment of Groundwater Pollution near Municipal Solid Waste Landfill Site. Lagos.

xxxix. Mora A.P., Calvo J.J.O., Cabrera F., Madejon E. (2005). Changes in enzyme activities and microbial biomass after "in situ" remediation of a heavy metal-contaminated soil. Applied Soil Ecology, 28, 125-137.

xl. Muller.G. (1969). Index of geo-accomulation in sediments of the Phine River. Geology Journal2, $108-118$.

xli. Murat R.C. (1970). Stratigraphy and Paleogeography of the Cretaceous and Lower Tertiary inSouthern Nigeria. Ibadan, Nigeria.: University of Ibadan Press.

xlii. Musa, H., Yakasai, I.A., Musa, H.H. (2004). Determination of lead concentration in well and boreholes in Zaria, Nigeria. Chemical Class Journal, Vol. 1, 14-18.

xliii. Niyi G., Felix 0. (2007). Assessment of Rural Water Supply Management in Selected Rural Areas of Oyo State, Nigeria.

xliv. Oboh I.P., Egun N.K., Olowo U.C., Nwaokolo J.I. (2018). Environmental Impact of Abattoir Waste Discharge on Groundwater Quality in Osubi Community, Delta State, Nigeria. International Journal of Health, Safety and Environments (IJHSE) Vol. 04, 269-279.

xlv. Oboh I.P., Osuala C.K. (2007). Assessment of Groundwater Quality Around Petroleum Tank Farm, in Ifie Community and Environs Warri Southern Nigeria. 543- 545.

xlvi. Ocheri, M.I., Mile I.I. (2010). Spatial and temporal variation in groundwater quality of Makurdi sedimentary formation. Journal of Geography, Environment and Planning, Vol. 6, 141-146.

xlvii. Odemerho F.O. Ejemeyovwi D.O. (2007). The Physiographic Provinces and Drainage Systems of Delta State, Nigeria, 9-17.

xlviii. Okpanachi A.S. (2012). Effects of Solid Waste Dumpsites on Groundwater Quality in Samaru, Nigeria.

xlix. Olobaniyi, S.O.B., Owoyemi, F.B. (2006). Characterization by factor analysis the chemical facies of groundwater in the Deltaic plain sand aquifer of Warri, western Niger Delta. African Journal of Science and Technology, Vol. 7, 7381.

l. Oyeku O.T., Eludoyin A.O. (2010). Heavy metal contamination of groundwater resources in a Nigerian urban settlement. African Journal of Environmental Science and Technology. 4.

li. Rafizul I.M., Alamgir M., Islam M.M. (2011, October 3 - 7). Evaluation of Contamination Potential of Sanitary Landfill Lysimeter Using Leachate Pollution Index. Proceedings of thirteenth International Waste Management and Landfill Symposium.

lii. Rauch J.N., Pacyna J.M. (2009). Earths Global Ag, Al, Cr, Cu, Fe, Ni, Pb, and Zn Cycles. 2.

liii. Reinhard M., Barker J., Goodman N. (1984). Occurrence and distribution of organic chemicals in two landfill leachate plumes. Environmental science \& technology, 18, 953-61.

liv. Reyment R.A. (1965). Aspects of Geology of Nigeria, (p. 133). Ibadan: University Press Nigeria.

lv. Ruiz R.G., Hinojosa M.B., Carreira J.A., Dick R.P. (2004). Soil moisture pre-treatment effects on enzyme activities as indicators of heavy metal contaminated and reclaimed soils. SoilBiology \& Biochemistry, 36, 1559-1568.

lvi. Sajad, M.M., Rahim S., Tahir T. (1998). Chemistry of groundwater of Rawalpinli/Isalama. 24thConference. Islamba.

lvii. Selvaraj K., Ram Mohan V., Szefer P. (2004). Evaluation of metal contamination in coastal sediments of the Bay of Bengal, India: geochemical and statistical approaches. MarPollut Bull 49, 174-185.

lviii. Short K.C. and Stauble A.J. (1967). Outline geology of the Niger Delta. Bull. Am. Ass. PetrolGeol. 54, 761-779.

lix. Singh. J., Kalamdhad. A. (2011). Effects of Heavy Metals on Soil, Plants, Human Health and Aquatic Life. International Journal of Research in Chemistry and Environment. 1., 15-21.

lx. Speira T.W., Kettlesb H.A., Percivalc H.J., Parshotam A. (1999). Is soil acidification the cause of biochemical responses when soils are amended with heavy metal salts? Soil Biology and Biochemistry, 31, 1953-1961. 
lxi. Sutherland R.A. (2000). Bed sediment-associated trace metals in an urban stream, Oahu, Hawaii.

lxii. . Environmental Geology 39, 611-626.

lxiii. Wigwe G.A. (1975). The Niger Delta: Physical Eastern States. Ethiope Publishing House, Benin City.

lxiv. Wong M.H., Chu L.M., Cheung K.C. (1994). Variations in the chemical properties of landfill leachate, Journal Environmental Managment 18., 105-117.

lxv. Yao H., Xu J., Huang C. (2003). Substrate utilization pattern, biomass and activity of microbial communities in a sequence of heavy metal polluted paddy soils. Geoderma 115, 139- 148.

lxvi. ZIAD A.M. (2004). An Experimental Investigation of Landfill Leachate Impact on Surrounding Soil. Geoenvironmental Research Centre, Cardiff School of Engineering, Cardiff University 